\title{
Consumer Attitudes Toward Advertisement and Brand, Based on the Number of Endorsers and Product Involvement: An Experimental Study
}

\author{
Tanti Handriana, ${ }^{*}$ and Wahyu Rahman Wisandiko ${ }^{2}$ \\ ${ }^{1}$ Faculty of Economics and Business, Universitas Airlangga, Indonesia \\ ${ }^{2}$ PT PLN Indonesia, Indonesia
}

\begin{abstract}
Utilizing endorsers in the advertising industry to promote products is currently on the rise, and employing celebrities as the endorsers is still the marketers' favorite method. This study aims to analyze the influence of the number of endorsers and the product's involvement on the consumers' attitude towards the advertisement and the brand. The research's approach used a $2 \times 2$ factorial experimental design. A total of 120 undergraduate students, who were further divided into 4 groups, were selected as the respondents of this study. The results show the differences in consumer attitudes towards advertisements and the brand, based on the number of endorsers and the product's involvement. The study also reveals that if there is low involvement with the product, multiple celebrity endorsements will generate a better consumers' attitude towards it than a single celebrity endorsement. Multiple celebrity endorsements will also generate a better attitude among the consumers towards the brand than a single celebrity endorsement will produce.
\end{abstract}

Keywords: attitude towards advertisement; attitude towards brand; experimental design; multiple celebrity endorsers; product involvement

JEL classification: M37

* Corresponding author's e-mail: tanti.handriana@feb.unair.ac.id 


\section{Introduction}

Celebrity serves as a source of advertisement or information regarding a brand and its product's attributes, with the intention of creating a pleasant and reassuring impression, as well as to attract the public's attention. Celebrity endorsements area popular marketing approach to making a product more noticeable, attractive and compelling to consumers (Wei and Li 2013). Companies hope to improve consumers' perceptions and the sales of their products and brands by affiliating with famous spokespeople (Amos et al. 2008 in Erfgen et al. 2016). A celebrity endorser is any individual who enjoys public recognition and who uses this recognition on behalf of a consumer good by appearing with it in an advertisement (McCracken 1989 in Roy and Pansari 2014). A study by Friedman, Termini, and Washington (1976) on the importance of celebrity endorsements of a particular brand reveals that the use of celebrity endorsements in advertisements will generate higher values of building trust in the advertisement, a better attitude towards the brand, and other dependent variables. Therefore, it is not surprising that companies are willing to spend fantastic amounts of money to pay for a celebrity to endorse their products.

The use of celebrities in advertising has increased remarkably over recent decades (Lee and Park 2014). The use of celebrities for products' promotions is a popular advertising strategy, which is used more frequently in Eastern than in Western countries (Kim and Jeong 2016). On a global scale, roughly every fifth advert includes a celebrity, making endorsements a widely used and popular strategy among marketers to promote consumer products and services (HalonenKnight and Hurmerinta 2010).
A celebrity endorsement is a popular marketing approach to making a product more noticeable, attractive and compelling to consumers (Wei and Wu 2013). Celebrity endorsements and best practices for celebrity adverts' utilization have long been debated. The reasons for the success of one campaign over another are sensitive subjects. The value of investigating other potential explanations, in terms of how consumers' attitudes and behaviors are influenced/ altered through use of celebrities as endorsers, is paramount (Shuart 2007).

Nowadays, it is even easier to find advertisements starring more than one celebrity, or using multiple celebrity endorsers (Hsu and McDonald 2002). Some marketers in Indonesia have also started using such strategies to promote their products. One of the examples is a television commercial for Axe Apollo perfume which utilizes multiple celebrity endorsers, namely three beautiful artists, Aura Kasih, Vicky Shu and Tyas Mirasih. Other examples are advertisements by Yamaha and Honda. In addition to competing with the quality and technology of their products, the top two motorcycle manufacturers in Indonesia also seem to race each other to sign up as many celebrities as possible to endorse their products. Recently, Yamaha has launched an advertisement campaign starring well-known comedians, Bajaj and Komeng, along with two Moto GP racers, Valentino Rossi and Jorge Lorenzo. Meanwhile, Honda has long been endorsed by Indonesia'stop celebrities, such as Daniel Mananta, Agnes Monica, and Nidji.

As a matter of fact, the marketers' strategy to use multiple celebrity endorsers is not unsubstantiated. Mowen and Brown (1981) claim that the use of multiple celebrity endorsers has undoubtedly helped marketers to 
influence consumers' perceptions. Hsu and McDonald (2002) also suggest that using multiple celebrity endorsers in advertisements is likely to affect more of the audience. Several previous studies have also revealed that multiple celebrity endorsements may have an effect on consumer attitudes (Rice et al. 2012; Pughazhendiet al. 2012).

According to Kelley's attribution theory (1967), people will determine the causality of an event based on their behavior or the behavior of others. Such as the Prospect Theory that explains that when presented in different ways, information can encourage an alteration inpeople's perspectives, preferences and actions (Hussein et al. 2014). Hence, if other people endorse a product, consumers are more likely to have a similar attitude and perception to those who promote the product. Based on this theory, Mowen and Brown (1981) then recommended that by utilizing multiple celebrity endorsers, marketers can effectively apply the concept of the Social Consensus Theory, since this technique is regarded as a good marketing strategy. Nonetheless, the effectiveness of multiple celebrity endorsements remains uncertain. This is due to the surprising findings in Um's study (2008) regarding multiple celebrity endorsements that yield an opposing result to some previous studies. This study reveals that multiple celebrity endorsements have no greater effect than single celebrity endorsements on consumers' attitudes toward brands and their advertisements.

Roozen and Claeys (2010) stated that in analyzing the effect of endorsers on the brands displayed in advertisements, it is also important to create a classification of high involvement and low involvement with the product. However, previous studies found the opposite. Pughazhendi et al. (2012), in his study, found that under the conditions of low involvement, the use of multiple celebrity endorsements could create a better consumers' response compared to a single celebrity endorsement. While in a high involvement condition there is no significant difference in the use of multiple or single celebrity endorsements. Similar results were also obtained by Yang (2006); Heinze (2010), and Rice et al. (2011).

Meanwhile, Park and Young (1983), in their research found that in the case of the cognitive involvement condition, attributesbased message contents significantly influenced the overall brand's attitude. In the case of the affective involvement condition, neither attributes-based message contents nor the attitude toward the commercial had any significant influence on the overall attitude to the brand, and in the case of the low involvement condition, the attitude toward the commercial significantly influences the overall attitude to the brand. Similarly, studies conducted by Kirby et al. (1998) involving women, reported stronger intentions than did women with low levels of involvement when seeking additional mammography information, regardless of the strength of the argument or cue favorability, and these women with low levels of involvement reported stronger intentions to seek more mammography information only when exposed to the favorable cue condition. Similar study results were also found by Rice et al. (2011); McAlister and Bargh (2016).

Product involvement is defined as a consumer's level of interest in a particular product (Solomon 2011). One of the wellknown theories on product involvement and the formation of consumers' attitudes is the Elaboration Likelihood Model (ELM) developed by Petty et al. (1983). The level of in- 
volvement may be influenced by a person, and/or situational or object factors (Celsi and Olson 1988).

This study is conducted with the aim of finding a justification for consumers' attitudes to advertising and brands, based on the number of endorsers and the level of involvement with the product. The findings of this study are expected to add references relating to the concept of endorsers, and product involvement's concepts. This study is conducted with an experimental research approach, in contrast to previous studies which were conducted by a survey approach.

Based on the Attribution Theory (Kelley 1967), the elaboration likelihood model (Petty et al. 1983), and some previous studies (Um 2008 and Pughazhendi et al. 2012), this study assumes that the number of endorsers and the product's involvement are related to the customers' attitudes towards brands and their advertisements. This study also expects that the effects of the interaction between the number of endorsers and the product's involvement in advertisements with multiple celebrity endorsements of low involvement products will generate the most positive consumers' attitudes towards the advertisements and the brand. Accordingly, the issues raised in this study are: (1) Are multiple celebrity endorsements better than a single celebrity endorsement in shaping consumers' attitudes towards the advertisements and brand? (2) Is low involvement better than high involvement in shaping consumers' attitudes towards the advertisements and brand? (3) How does the number of endorsers affect the customers' attitudes towards the advertisements and brand at two different levels of involvement with the product?

\section{Literature Review}

\section{Single and Multiple Celebrity Endorsements}

Advertisers commonly use celebrity endorsers to increase the effectiveness of advertising to persuade consumers (Chen et al. 2013). A celebrity endorser is defined as any individual who enjoys public recognition and who uses this recognition when they appear in an advertisement in front of consumers, and who often have distinctive attributes such as attractiveness and trustworthiness (Silvera and Austad 2004). Research into celebrity endorsements could be divided into three distinct streams, namely: source credibility, which has its roots in psychology; congruence or match-up; and meaning transfer (Roy et al. 2013). Utilizing one celebrity to endorse products in an advertisement is commonly known as a single celebrity endorsement.

Meanwhile, multiple celebrity endorsemens refer to the use of two or more celebrities in an advertisement (Hsu and McDonald 2002). According to Um (2008), there are two types of multiple celebrity endorsements. The first type is a multiple celebrity endorsement in which two or more celebrities collaborate to support one product in the same advertisement, while the second type is a multiple celebrity endorsement in which two or more celebrities support the product but in a different series of advertisements. This study refers to the first type of multiple celebrity endorsement, in which the celebrities support one product in the same advertisement. The use of celebrities in endorsements is often designed to improve the consumers' attitudes 
toward the focal brand and to increase their purchase intentions toward that brand (Amos et al. 2008 in Erfgen et al. 2016).

\section{Attribution Theory}

The attribution theory (Kelley 1967) states that a person determines the causality of an event based on his/her behavior or the behavior of others. Social consensus is a component of the attribution theory and refers to the tendency to generalize different matters (Tripp 1994). Social consensus will arise once a person notices other people using the same product. In the context of advertising, it implies that consumers tend to have similar perceptions with others who use similar products (Schiffman and Kanuk 2014). Therefore, if other people endorse a product, consumers will be more likely to have the same attitudes and perceptions as those who support the product. Based on this theory, researchers then recommend that the use of multiple celebrity endorsers will enable marketers to effectively apply the concept of the social consensus theory, which is regarded as a good marketing strategy (Mowen and Brown 1981).

Based on the explanation above, this study formulates the following hypotheses:

$H_{1}$ : Consumers' attitudes towards advertisements will be better for advertisements with multiple celebrity endorsements than for those with a single celebrity endorsement.

$H_{2}$ : Consumers' attitudes towards a brand will be better for advertisements with multiple celebrity endorsements than for those with a single celebrity endorsement.

\section{Product Involvement}

Product involvement is defined as the consumers' absolute perception regarding the importance of product categories, based on their needs, values, and interests (Zaichkowsky 1985). Goldsmith and Emmert (1991) conceptualized product involvement as being consumers' interest, enthusiasm, and preferences for certain product categories. Meanwhile, Mowen (1995) perceived involvement as important and defines it as the consumers' interest in the consumption and disposition of goods, services, or ideas. As involvement increases, consumers will have a greater motivation to observe, understand, and elaborate information regarding their purchases. According to Schiffman and Kanuk (2014), purchasing products using a personal interest or minimal effort is referred to as a low involvement purchase, while that with a high level of involvement through complex inquiriesis called a high-involvement purchase. A high involvement product is a product purchased only after long and careful consideration, which may range from inquiries about the product to careful evaluation of the different brands, or where the motivation and ability to process the message are high. Meanwhile, a low involvement product is usually a consumable item that requires no complicated evaluation process on the part of the consumer prior to its purchase, or where the motivation and/or ability to process a message is low. Involvement is another construct receiving considerable attention in advertising literature, the proposition is that the more involved an individual consumer is when faced with an advertisement, the morehe or she will actively attempt to determine how the advertrelates to their own needs andwants (Chaefer and Keillor 1997).

\section{Elaboration Likelihood Model (ELM)}

The Elaboration Likelihood Model (ELM) is a theory developed by Pettyet et al. (1983) suggesting the formation and changes 
in consumers' attitudes. ELM is a persuasi on theory, as it attempts to predict when and how individuals will and will not be persuaded by a message (Littlejohn and Foss 2008). Peter and Olson (2004) argue that factors determining the type of persuasion that occurs through the central or peripheral routes are the level of motivation and the ability to process information. The processing of information and the attitude changes that occur in a person are affected by how much and how deeply the information is processed. The ELM holds that, under conditions of low involvement, individuals conserve their cognitive resources and allow peripheral cues (such as endorser characteristics) to influence their attitudes. In contrast, under conditions of high involvement, their attitudes are influenced through a central route. In such cases, individuals carefully consider the pros and cons of the message (Chaefer and Keillor 1997).

\section{Social Adaptation Theory}

The social adaptation theory (Kahle and Homer 1985) suggests that the importance of information will determine its impact on consumers' attitudes. Homer and Kahle (1990) explained that if we take print media as a stimulus, in advertisements for products with low involvement, the audience will only glance briefly at the advertisements for a second or two and then move on to the next page. This happens because consumers have no desire to exert a great effort insuch a low involvement situation (Chung and Zhai 2003). The information to be read or considered during that short period of time is the kind of information that can have an impact on consumers. As a result, consumers can only remember a few things while glancing at the advertisements. The product's name and other visual impressions are possibly all the information noticed by the consumers in this con- dition, and whether the advertisements present weak or strong arguments will be of no concern to them. In contrast, for products with high involvement, consumers will spend more time reading the advertisements and focus more on the arguments rather than just the visual impression.

Based on the elaboration likelihood model and the social adaptation theories, the second set of hypotheses are formulated as follows:

$H_{3}$ : Consumers' attitudes toward advertisements will be better for advertisements featuring celebrities with a low involvement product than a high involvement product.

$H_{4}$ : Consumers' attitudes towards a brand will be better for advertisements featuring celebrities with a low involvement product than a bigh involvement product.

This study also examines the effects of the interaction between the number of endorsers and the product's involvement. Based on the ELM theory suggested by Petty et al. (1983), the peripheral cues (in this study the celebrity endorsers) will be more influential in consumers' responses when consumers are in a low involvement condition; whereas, in a high involvement condition, the consumers will focus more on the strength of the arguments and the attributes of the product. Accordingly, it can be hypothesized that the use of multiple celebrity endorsements will significantly affect the consumers' attitudes towards the brand and its advertising only in the low involvement product category, while with the high involvement products there will not be a significant difference. Saleem (2007) and Pughazhendi et al. (2012) also support the ELM theory as they confirm that the use of endorsers has a greater impact on consumers' attitudes in the low involvement product category than on those in the high involvement category. Thus: 
$H_{5}:$ Multiple celebrity endorsements will generate better consumer attitudes toward an advertisement than a single celebrity endorsement for low involvement products; whereas, in the case of high involvement products, the opposite is true.

$H_{6}:$ Multiple celebrity endorsements will generate better consumer attitudes toward a brand than a single celebrity endorsement for low involvement products; whereas, in the case of high involvement products, the opposite is true.

\section{Methods}

\section{Experimental Design}

This study applied a factorial design 2 (single versus multiple) x 2 (high versus low involvement) and betweensubject methods. Factorial design is a statistical experimental design used to measure the impact of two or more independent variables at various levels and to allow for the interaction among the variables (Malhotra 2010). Meanwhile, the subject is an experimental design in which each subject only receives one treatment condition (Churchill 2002).

The steps undertaken in this study are preliminary tests I and II, a check manipulation, a pretest, and the main test. Preliminary test I was conducted to determine the category, either high involvement or low involvement, while preliminary test II was to determine the endorser. In preliminary test I, conducted on 40 undergraduate management students, each participant was given a list of goods (a laptop, mobile phone, toiletries, snacks, soft drink, motorbike and watch), then the participants were asked to name one item that most needed an information search process and careful consideration before making a purchase decision, and one other item that required the least information and careful consideration before making a purchase decision. From the first preliminary test we found that mobile phones were most often mentioned as the goods that needed the lengthiest information search processes and most careful consideration before making a

\section{Figure 1. Research Model}

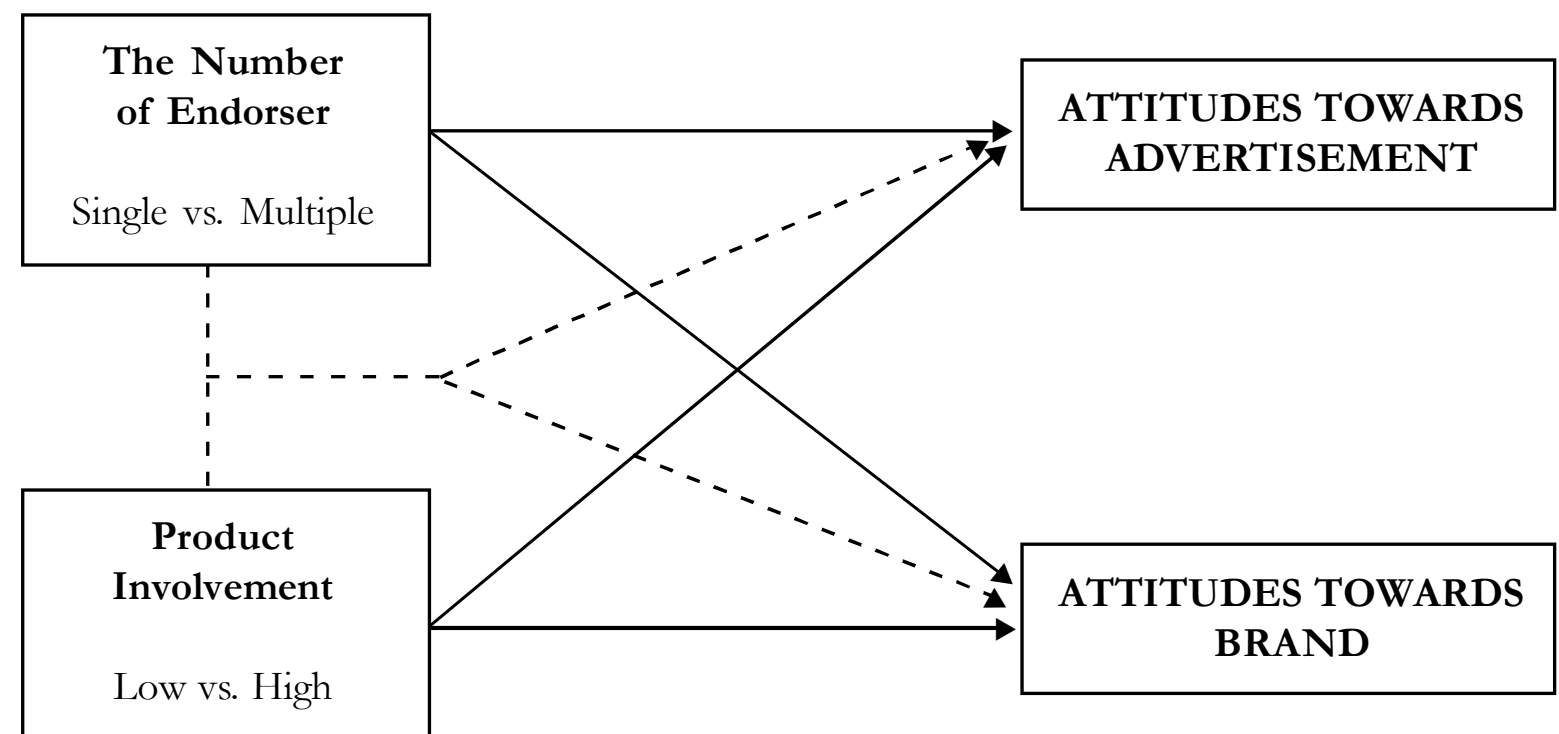

This figure shows the research model, which describes relatioship between variables are the number endorser (single vs multiple), produc involvement (low vs high), attitude towards advertisement, and attitude towards brand. 
purchase decision, so they were selected for the high involvement category product. Whilst snack foods were mostly mentioned as the items that do not require much, if any, information seeking or careful consideration before making a purchase decision, and they were selected for the low involvement category product. In the second preliminary test, followed by forty participants, the participants were given a list of the names of popular Indonesian celebrities, and were then asked to choose the 3 names that held the most attraction, credibility and high compatibility for them. The most celebrated celebrities are the celebrities who will be selected as the endorsers in this research. From the second preliminary test we obtained six names for our celebrity endorsers.
The manipulation checks implemented on the undergraduate students were used to ensure that the participants understood the stimulus manipulation designed by the researcher. The objective of the manipulation check was to as certain whether the participants understood the type and number of endorsers and brands, and the products' involvement levels.

To obtain accurate information from the participants it was necessary to check the accuracy of the measuring instruments in this study. So, before the main test was conducted, it was necessary to perform a pretest to test the participants' understanding of the questionnaire, the grammatical instructions in the questionnaire, and how to fill it out. The pretest also served to ensure that the manipula-

Figure 2. Advertisement Designs for Each Scenario
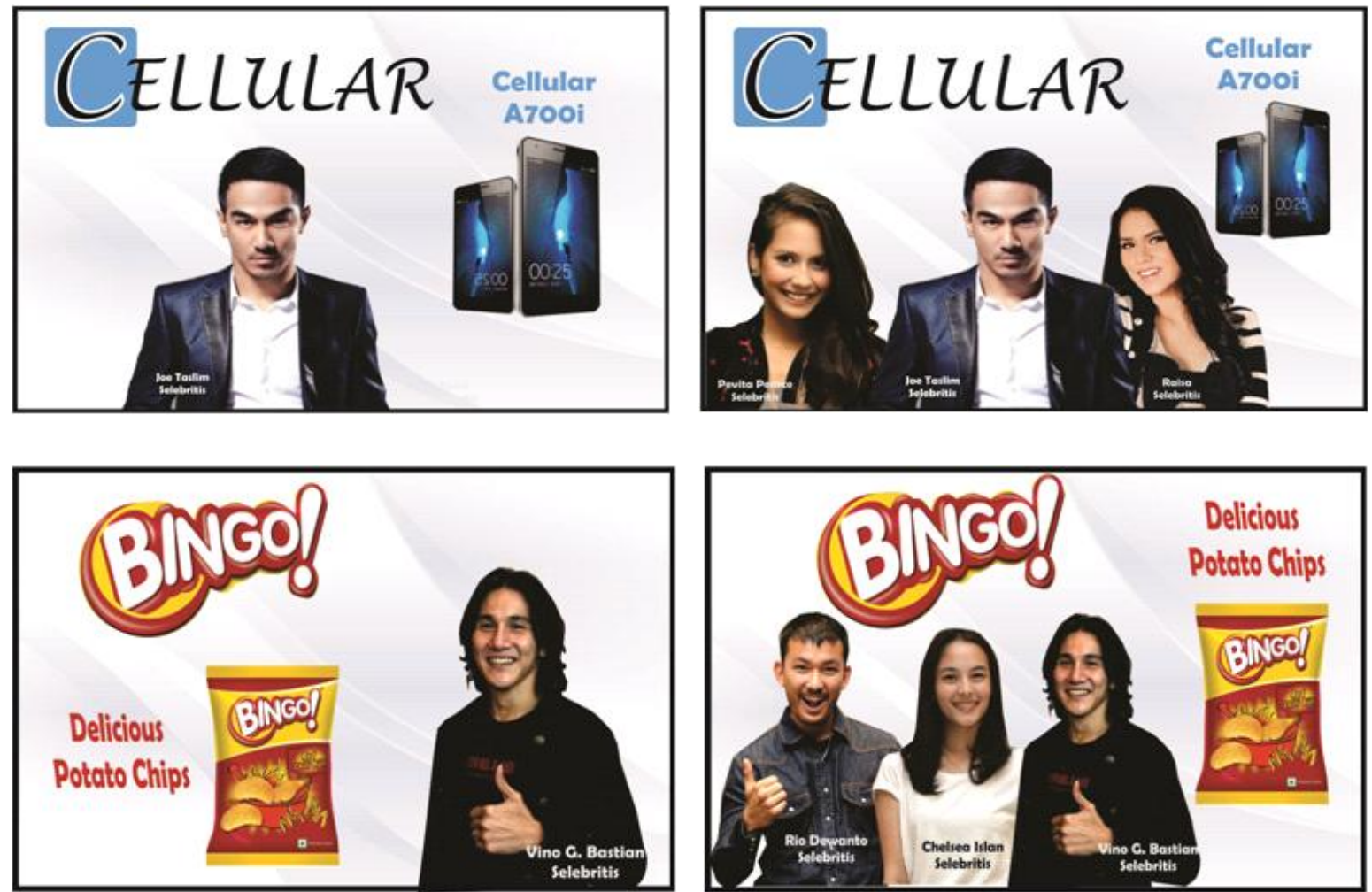

This figure shows the four scenario from this study: 1. Single endorser \& low product involvement; (2) multiple endorsers \& low product involvement; (3) single endorser \& high product involvement; (4) multiple endorsers and high product involvement. 
tion of the variables that have been designed can be understood by the participants. The pretest was performed on 30 undergraduate students.

The types of products used in this study were snacks for the low involvement category, and mobile phones for the high involvement category. These products' selections were based on the preliminary test results. For the products' brands, this study used fictitious brands, namely BINGO (for the snacks) and CELLULAR (for the mobile phones) with the aim of minimizing any potential bias that may result from brand images attached to any existing brands.

As for the celebrities used as endorsers in this research, six famous celebrities were selected through the preliminary test to serve as endorsers inthe designed advertisements. They were Joe Taslim, Pevita Pearce, Raisa, Rio Dewanto, Vino G. Bastian, and Chelsea Islan. Based on a $2 \times 2$ factorial design, there were 4 print advertisements with two types of celebrity endorsement (single versus multiple) in two product categories (low versus high involvement). In other words, for the low involvement product category, there were two different advertisements, one with a single celebrity endorser, and the other with multiple celebrity endorsers. Similarly, for the high involvement product category, there were also two different advertisements of the same kind.

Then, each participant saw only one version of the advertisements before filling in a questionnaire to elicit his/her response. The advertisements were made witha similar format and design for each product category, and only distinguished by the number of endorsers displayed. Product images and the endorsers' photos were also a similar size for each category, in order to avoid differences in understanding the advertisements among the participants.

\section{Definition of Operational Variables}

\section{The number of endorsers in the advertisements.}

The number of endorsers refers to the total number of endorsers used in an advertisement. In this study, as a variable, the number of endorsers was divided into two, namely single (one person) and multiple endorsers (3 persons). To check the participants' understanding about the manipulated variable of the number of endorsers, an open question was employed as an indicator. The question was "How many endorsersdo you see on the displayed advertisement?"

\section{Product involvement}

Zaichkowsky (1985) defines product involvement as the consumers' perception toward the importance of the products' categories, based on their needs, values and interests. To measure the level of involvement with the product, this study employed indicators developed by Zaichkowsky (1985), Schiffman and Kanuk (2014), and Belch and Belch (2004). According to them, product involvement is concerned with the search for information, the complexity of thought and the consumers' considerations prior to purchase. The indicators were as follows: (1) products in the displayed advertisements require a detailed inquiry prior to making a purchasing decision (e.g. via the internet, other people, magazines, etc.); (2) products in the displayed advertisements require acomplex thought process prior to making a purchase decision; and (3) products in the displayed advertisements require careful consideration prior to making a decision to purchase or not. 


\section{Attitudes towards the advertisements}

Assael (2004) defines the attitude toward an advertisement as the consumers' tendency to respond well or not toward a particular advertisement. This attitude toward an advertisement also refers to the consumers' likes and dislikes in general toward a particular advertisement's stimulus (Mowen and Minor 2001). In this study, the attitude toward an advertisement is defined as the consumers' feelings and evaluation/assessment toward the viewed advertisement. To measure the attitude toward the advertisement, there were 4 items used with 7 semantic differential scales adopted from Mitchell and Olson (1981) and which were described as follows: (1) Dislike/like; (2)bad/good; (3)uninteresting/interesting; (4)annoying/pleasing.

\section{Attitude towards the brand}

Kotler and Keller (2016) define a brand as a name, form, sign, symbol, or design, or a combination thereof, which isintended to identify products or services from one seller or group of sellers, and to differentiate them from their competitors. Furthermore, according to Assael (2004), the attitude towards a brand refers to the consumers' tendency to evaluate brands so as to form an attitude about whether the brand is positive or not. In addition, Mitchell and Olson (1981) define the attitude towards a brand as an internal evaluation of the individual against a brand. In this study, the attitude towards a brand is defined as the consumers' feelings and evaluation/assessment toward the brand. To measure the attitude towards the brand, 4 items with 7 semantic differential scales, adopted from Mitchell and Olson (1981) were used. The 4 items were: (1) Dislike/like; (2)bad/good; (3)uninteresting/interesting; (4)annoying/pleasing.

\section{Research Participants}

The number of participants in this study followed the experimental cell number that consisted of 4 groups. As each group consisted of 30 people, the total number of participants in this study was 120 . The participants were undergraduate students selected using a non-probability sampling method, namely the purposive sampling method. The participants were chosen because they met the criteria, such as being undergraduate students who used smartphones (high involvement) and/or undergraduate students who consumed snacks (low involvement). Justification for the use of students as the participants is that, according to Podsakoff and Dalton (1987), they are available, convenient, cheap, and they are more controllable.

\section{Results and Discussion}

\section{Validity and Reliability Tests}

The validity test was measured by calculating the item's total correlation for all of indicators. Although factor loadings of \pm 0.3 to \pm 0.4 are minimally acceptable, values greater than \pm 0.5 are generally considered necessary for practical significance (Hair et al. 2014). Reliability was assessed by Cronbach's alpha; the generally agreed upon lower limit for Cronbach's alpha is 0.7 (Hair et al. 2014). The results of the validity and reliability tests for both the dependent variables are presented in Table 1 and Table 2.

Based on the results of the validity and reliability tests, as displayed in Table 1 , it can be concluded that the indicators used to measure the variable of the attitude towards an advertisement were rated valid and reliable. This was indicated by the item's total corre- 
Table 1. Validity and Reliability Tests on the Variable of Attitudes Towards Advertisement

\begin{tabular}{ccccc}
\hline Indicator & Factor Loadings & Remark & Cronbach's Alpha & Remark \\
\hline SI1 & 0.689 & Valid & & \\
SI2 & 0.786 & Valid & & Reliable \\
SI3 & 0.705 & Valid & 0.873 & \\
SI4 & 0.741 & Valid & & \\
\hline
\end{tabular}

This table shows the testing for validity and reliability tests on the variable of attitudes towards advertisement. In the second column shows the factor loading more than 0.5. There are incate that variable is valid. The fourth column shows the Cronbach's Alpha is more than 0.7. There are indicate that the variable is reliable.

Table 2. Validity and Reliability Tests on the Variable of Attitudes towards Brand

\begin{tabular}{ccccc}
\hline Indicator & Factor Loadings & Remark & Cronbach's Alpha & Remark \\
\hline SM1 & 0.706 & Valid & & \\
SM2 & 0.683 & Valid & & Reliable \\
SM3 & 0.753 & Valid & 0.859 & \\
SM4 & 0.681 & Valid & & \\
\hline
\end{tabular}

This table shows the testing for validity and reliability tests on the variable of attitudes towards brand. In the second column shows the factor loading more than 0.5. There are incate that variable is valid. The fourth column shows the Cronbach's Alpha is more than 0.7. There are indicate that the variable is reliable.

lation values forthe four indicators of more than 0.3 and Cronbach's alpha values of more than 0.6. Hence, these four indicators were already suitable for use as a measuring tool for the variable ofthe attitudes towards the advertisement.

Based on Table 2, which displays the results of the validity and reliability test onthe variable of the attitudes towards the brand, it is apparent that the indicators used to measure the variable of the attitudes towards the brand were rated valid and reliable. This was indicated by the item's total correlation values for the four indicators of more than 0.3 and Cronbach's alpha values of more than 0.7. Therefore, these four indicators were already suitable for use as a measuring tool for the variable of the attitude towards the brand.

\section{Homogeneity Test}

Table 3 displays the result of the homogeneity test with the Levene's test. Levene's test examines the Analysis of Variance (ANOVA)'s assumption regarding the variance value of the data as equal (equal variance). Table 3 shows that each variable had significant values above 0.05 . This indicates that the variables on the attitudes towards the advertisement and brand had the same (homogeneous) variance and the assumption ofthe homogeneity of the variance was met.

Table 4 contains a summary of the results of the Multivariate Analysis of Variance (MANOVA) test. In this table, the attitude towards the advertisement showed an $\mathrm{F}$ value of 4.232 and was significant at a 0.05 ( $p=$ 
0.042) for the variable on the number of endorsers. The results showed that the difference in the number of endorsers, as perceived by the consumers, generated different attitudes toward the advertisement. The data also showed that multiple celebrity endorsements resulted in better consumer attitudes towards the advertisement $($ mean $=4.716)$ as compared to the single celebrity endorse- ment $($ mean $=4.345)$. The consumers' attitudes toward the advertisement will be improved by advertisements with multiple celebrity endorsements than for those with just a single celebrity endorsement. Hence, Hypothesis $H_{1}$ was accepted. According to Wang et al. (2015), the fit among multiple celebrities selected to endorse the brand matters in influencing the consumers' attitudes.

Table 3.Levene's Test on Homogeneity of Variance

\begin{tabular}{lcccc}
\hline \multicolumn{1}{c}{ Variable } & F & df1 & df2 & Sig \\
\hline Attitude towards Advertisement & 1.893 & 3 & 116 & 0.135 \\
Attitude towards Brand & 0.893 & 3 & 116 & 0.447 \\
\hline
\end{tabular}

This table shows the testing for homogeneity of variance. In fifth coloum shows the significance value more than 0.05, its indicate the variable is homogeneous

Table 4. Summary of MANOVA Test Results

\begin{tabular}{cccccccc}
\hline \multirow{2}{*}{ Variable } & \multicolumn{3}{c}{$\begin{array}{c}\text { Attitudes towards } \\
\text { Advertisement }\end{array}$} & \multicolumn{3}{c}{ Attitudes towards Brand } \\
\cline { 2 - 7 } & Mean & F & Sig & Mean & F & Sig \\
\hline Number of Endorsers: & & & & & & \\
Single & 4.345 & & & 4.179 & & \\
Multiple & 4.716 & 4.232 & .042 & 4.587 & & .012
\end{tabular}

\section{Product Involvement:}

$\begin{array}{lllllll}\text { High } & 4.316 & & & 4.075 & & \\ \text { Low } & 4.745 & 5.668 & .019 & 4.363 & .000\end{array}$

\section{Number of Endorsers * Product Involvement:}

Single Endorser*
High Involvement
Multiple Endorsers*
High Involvement
Single Endorser*
Low Involvement

Multiple Endorsers* Low Involvement

$$
4.183
$$$$
.942
$$

4.450

4.508

4.139
3.900

2.425

4.450

4.181

.045

$4.983 \quad 4.925$

This table shows the testing for MANOVA Test for hypotheses testing 
The attitude towards the brand resulted in an $F$ value of 6.515 and was significant at a0.05 ( $p=0.012)$ for the number of endorsers variable. The results suggested that the difference in the number of endorsers, as perceived by the consumers, generated different attitudes towards the brand. The data also showed that multiple celebrity endorsements led to better consumer attitudes towards the brand (mean $=4.587$ ) than the single celebrity endorsement (mean=4.179). Consumer attitudes towards the brand will be improved by advertisements with multiple celebrity endorsements than by those with a single celebrity endorsement. Consequently, Hypothesis $\mathrm{H}_{2}$ was also accepted.

These findings reveal that the difference in the number of endorsers featured in an advertisement is able to provide different results for the consumers' attitudes toward an advertisement and brand. The MANOVA test results also show that the use of multiple celebrity endorsements may result in a better consumer attitude than a single celebrity endorsement. Accordingly, Hypotheses $H_{1}$ and $\mathrm{H}_{2}$ were supported and are in accordance with the previous theories and research (Mowen and Brown 1981; Hsu and McDonald 2002; Rachita et al. 2013, Bhagyashree and Solanki 2015).

The data of the MANOVA's test resultin Table 4 on the attitudes toward the advertisement showed an $\mathrm{F}$ value of 5.668 and was significant at $\alpha 0.05(p=0.019)$ for the product involvement variable. The results showed that the difference in the level of involvement with the product would generate different attitudes towards the advertisement. The data also showed that low involvement resulted in better consumer attitudes toward the advertisement (mean $=4.745)$ as compared to high involvement $($ mean $=4.316)$.
Consumer attitudes toward the advertisement will be better for advertisements featuring celebrities with a low involvement product than with a high involvement product. Hence, Hypothesis $H_{3}$ was accepted.

Additionally, the data from the MANOVA's test result in Table 4 on the attitudes towards the brand revealed an $\mathrm{F}$ value of14.363 and was significant at a0.05 (p> $0.0001)$ for the product involvement variable. The results confirmed that the difference in the level of involvement with the product would prompt different attitudes toward the brand. The data also showed that low involvement resulted in better consumer attitudes to the brand (mean $=4.688$ ) than high involvement (mean $=4.075)$. The consumers' attitudes towards the brand will be better for advertisements featuring celebrities with a low involvement product than with high involvement products. Consequently, Hypothesis $\mathrm{H}_{4}$ was also accepted.

Hence, these results indicate that differences in the level of the product's involvement have a significant influence on the consumers' attitudes towards the advertisement and brand. These led to a conclusion that the advertisement in the low involvement product category generated better consumer attitudes towards the advertisement than that in the high involvement product category. Accordingly, Hypotheses $H_{3}$ and $H_{4}$ were accepted, which was consistent with the elaboration likelihood model suggested by Petty etal. (1983), which stated that the level of product involvement is one of the important variables affecting the formation of consumers' attitudes and dividing the message processing through two different paths, namely the central and peripheral routes. If consumers have a high degree of involvement in a product, their attitudes are shaped through 
the central route, as they will be influenced by considerations of the message's content regarding the brand's features, attributes and benefits. Meanwhile, if consumers have a very low involvement, their attitude formation occurs through the peripheral route, in which simple signs, objects, or celebrities play a significant role in the evaluation process (Petty et al. 1983). Thus, the findings in this study are in line with the findings of previous research (Rice et al. 2012; Petty et al. 1983).

Based on the data from the MANOVA's test results in Table 4, on average multiple celebrity endorsements for low involvement products generated better consumer attitudes towards the advertisement than the single celebrity endorsement did (4.983 > 4.508), and their differences also met the significance value of $a=0.05(p=0.046)$. High involvement products, even though multiple celebrity endorsements, also resulted, on average, in better attitudes towards the advertisement as compared to a single celebrity endorsement $(4.450>4.183)$, the significance value was not met because $a=0.05(p=0.336)$. Accordingly, Hypothesis $H_{5}$ was accepted.

The data also showed that forlow involvement products, multiple celebrity endorsements generated better consumer attitudes toward the brand than a single celebrity endorsement did $(4.925>4.450)$, on average, and the differences between them also met the significance value of $\mathrm{a}=0.05$ $(\mathrm{p}=0.045)$. High involvement products, even though multiple celebrity endorsements, resulted, on average, in better consumer attitudes toward the brand than a single celebrity endorsement did $(4.250>3.900)$, the significance value was not met since $\mathrm{a}=0.05$ (0.125). Hence, Hypothesis $H_{6}$ was accepted.
The analysis and discussion reveals that with low involvement products, the consumers' attitudes toward the advertisement and brand were better when using multiple celebrity endorsements than a single celebrity endorsement. For a low involvement product, multiple celebrity endorsements will generate a better consumers' attitude towards the advertthan a single celebrity endorsement can. For a low involvement product, multiple celebrity endorsements will generate better consumer attitudes towards the brand than a single celebrity endorsement will. But with high involvement products, both multiple and single celebrity endorsements generate the same consumers attitude towardthe adverts. Also for high involvement products, multiple celebrity endorsements do not generate any different consumer attitudes toward the brand than single celebrity endorsements do. Therefore, Hypotheses $H_{5}$ and $H_{6}$ were accepted. These results reinforce the theory developed by Petty etal. (1983) and are in parallel with previous studies conducted by Pughazhendi et al. (2012) in India, which also led to similar results, and Rice et al. (2012).

\section{Conclusion}

The results showed that there were differences in the consumers' attitudes towards advertisements and brands, based on the number of endorsers featured in an advertisement. Advertisements featuring multiple celebrity endorsers were able to better shape the consumers' attitudes than those displaying only a single celebrity endorser. These also indicated that there were differences in the consumers' attitudes toward advertisements and brands based on the level of involvement with the product, as perceived by the con- 
sumers. Advertisements in the low product involvement category were capable of producing better consumer attitudes toward the advertisement than those in the high product involvement category.

From the analysis of the interaction's effect, the use of multiple celebrity endorsements was more effective in generating improved consumer attitudes toward advertisements and brands only for the low involvement products; whereas for the high involvement products, the differences did not show significant results.

The managerial implication from this study is that, for businessmen with low involvement products, the use of multiple endorsers will be more effective than the single endorser, because using multiple endorsers has a better impact on the consumers' attitudes to advertising and the brand. Meanwhile, for the businessman with high involvement products, the use of either a single endorser or multiple endorsers for their product's advertisements does not make a significant difference on the effect of consumers' attitudes to the advertisement and brand.

The first drawback of this research lies in the stimulus design of the advertisements, which was regarded as being rather unrealistic by most of the participants. This was due to their very simple design, displaying only the logo and the product's image, as well as the endorsers. In addition, the use of ficti- tious brands in the advertisements made the participants feel that the advertisements were fabricated and unreal, which eventually affected their responses. For further research, the use ofa more realistic and not-too-simplistic design for the advertisements is recommended, in order to convince the participants that the advertisements are real, and thus, eventually evoking better responses.

Second, this study only measured the effectiveness of an advertisement to determine the consumers' attitude to it, but not their intentions or future actions. The effects of such variables as the number of endorsers and the product's involvement in the advertisements were only measured by the consumers' attitudes toward the advertisement and brand. For further research, it would be better to add some other dependent variables, such as purchase intentions.

Another limitation is that the study only manipulated the variables of the number of endorsers and involvement with the product in measuring the consumers' attitudes. As a matter of fact, there are many other factors that influence the effectiveness of the use of multiple celebrity endorsements, such as the compatibility of the endorser and product, the source credibility of the endorser, as well as the sex and age of the participants. Therefore, future studies are expected to combine these variables in order to measure the effectiveness of the multiple celebrity endorsement.

\section{References}

Assael, H. 2004. Consumer Behavior: A strategic approach. Boston, MA: Houghton Mifflin Company.

Belch, G.E and M.A. Belch. 2003. Advertising and Promotion an Integrated Marketing Communication Perspectives. $6^{\text {th }}$ ed., New York: McGraw-Hill, Inc.

Bhagyashree S. and S. Solanki. 2015. What Is More Effective? Single Celebrity Versus Multiple Celebrity: A Study Relative Effectiveness of Both Type of Print Advertisements on Consumer' Perception. International Journal of Research - Granthaalayah 3 (9): 23-35. 
Celsi R. L. and J. C. Olson. 1988. The role of involvement in attention and comprehension processes. Journal of Consumer Research 15: 210-224.

Chaefer A. and B. Keillor. 1997. Effective use of endorsements in advertising: The relationship between "Match-Up" and involvement. The Journal of Marketing Management 7 (2): 23-33.

Chung, H.and X. Zhai. 2003. Humor Effect On Memory and Attitude: Moderating Role of Product Involvement. International Journal of Advertising 22 (1): 117-144.

Churchill G. A. 2002. Fundamentals of experimental design For DNA microarrays. Nature Genetics Supplement 32: 490-495.

Erfgen C., H. Sattler, and I. V. Villeda. 2016. Effects of celebrity endorsers for multiple brands on attitudes and purchase intentions. Schmalenbach Bus Rev 17: 49-67.

Friedman, H., S. Termini, and R. Washington. 1976. The effectiveness of advertisements utilizing four types of endorsers. Journal of Advertising 5 (3): 22-24.

Goldsmith, R.E. and J. Emmert. 1991. Measuring product-category involvement: A multitrait-multimethod study. Journal of Business Research 23: 363-371.

Hair, J. F., W.C Black, B.J. Babin, and R.E. Anderson. 2014. Multivariate Data Analysis (7 ${ }^{\text {th }}$ ed.), Edinburgh Gate, Harlow-Essex: Pearson Education.

Heinze, T. 2010. Cue congruency and product involvement effects on generation Y attitudes. Research in Consumer Behavior 12: 75-99.

Hollensen, S. and C. Schimmelpfennig. 2013. Selection of celebrity endorsers: A case approach to developing an endorser selection process model. Marketing Intelligence and Planning 31 (1): 88-102.

Homer, P.M., and L.R. Kahle. 1990. Source expertise, time of source identification, and involvement in persuasion: An elaborative processing perspective. Journal of Advertising 19 (1): 30-39.

Hsu, C., and D. McDonalds. 2002. An examination on multiple celebrity endorsers in advertising. Journal of Product and Brand Management 11 (1): 19-29.

Hussein A. S., V. Manna, and D. Cohen. 2014. The impact of message framing and source credibility on breastfeeding intention: A social marketing approach. Gadjah Mada International Journal of Business 16 (2): 93-109.

Jung-Gyo, L., and J. Park. 2014. The effects of endorsement strength and celebrity-product match on the evaluation of a sports related product: the role of product involvement. International Journal of Sports Marketing and Sponsorship 16 (1): 50-69.

Kahle, L. R., and P. M. Homer. 1985. Physical attractiveness of celebrity endorser: A social adaptation perspective. Journal of Consumer Research 11 (4): 954-961.

Kelley, H. 1967. Attribution theory in social psychology. In D. Levine (Ed.), Nebraska Symposium on Motivation 15 (192-238). Lincoln: University of Nebraska Press.

Khong, K. W., and Y. L. Wu. 2013. Measuring the impact of celebrity endorsement on consumer behavioural intentions: A study of Malaysian consumers. International Journal of Sports Marketing and Sponsorship 14 (3): 2-22.

Kim H., and J. Jeong. 2016. Effect of celebrity endorsement in marketing of musicals: Poster versus social networking site. Social Behavior and Personality 44 (8): 1243-1254.

Kirby, S. D., J. R. Ureda, R. L. Rose, and J. Hussey. 1998. Peripheral cues and involvement level: Influences on acceptance of a mammography message. Journal of Health Communication 3: 119-135. 
Kotler, P., and K. L. Keller. 2016. Marketing Management (15 $5^{\text {th }}$ d.), New York: Pearson.

Littlejohn, S. W., and A. F. Karen. 2008. Theories of Human Communication ( $9^{\text {th }}$ ed.). Belmont, CA : Thomson Wadsworth.

Malhotra, N. K. 2010, Marketing Research: An Applied Orientation (6 ${ }^{\text {th }}$ ed.). Upper Saddle River, New Jersey: Pearson Education, Inc.

McAlister, A. R., and D. Bargh. 2016. Dissuasion: The elaboration likelihood model and young children. Young Consumers 17 (3): 210-225.

Mitchell, A. A., and J. C. Olson. 1981. Are product attribute beliefs the only mediator of advertising effects on brand attitude? Journal of Marketing Research 18 (3): 318-332.

Mowen, J. C., and M. Minor. 2001. Consumer Behavior: A Framework (2 $2^{\text {nd }}$ ed.). Upper Saddle River, New Jersey: Prentice-Hall.

Mowen, J.C., and S.W. Brown. 1981. On explaining and predicting the effectiveness of celebrity endorsers. Advances In Consumer Research 8 (1):437-441.

Mowen, J.C. 1995. Consumer Behavior (4 ${ }^{\text {th }}$ ed.). New Jersey: Prentice-Hall.

Park C. W, and S. M. Young. 1983. Types and levels of involvement and brand attitude formation. Advances in Consumer Research 10: 320-324.

Peter, J.P. and J.C. Olson. 2004. Consumer Behavior and Marketing Strategy $\left(7^{\text {th }}\right.$ ed.). New York: McGrawHill.

Petty, R. E., J.T. Cacioppoand, and D. Schumann. 1983. Central and peripheral routes to advertising effectiveness: The moderating role of involvement. Journal of Consumer Research 10: 135-146.

Podsakoff, P. M., and D. R. Dalton. 1987. Research methodology in organizational studies. Journal of Management 13: 419-441.

Pughazhendi A., K.A. Baskaran, M. R.Prakash, and R. N. Balamurugan. 2012. A study on effectiveness of multiple and single selebrity endorsement on considerable product advertisements in Chennai perceptive, India. Far East Journal of Psychology and Business 6 (2): 11-18.

Rachita J. M., B. K. Nirmal; and P. K. Priya. 2013. Exploring the impact of single celebrity vs.multiple celebrity endorsement on consumer's brand choice behavior. International Journal of Marketing and Business Communication 3: 1-9.

Rice, D. H., K. Kelting, and R. J. Lutz. 2012. Multiple endorsers and multiple endorsements: The influence of message repetition, source congruence and involvement on brand attitudes. Journal of Consumer Psychology 22: 249-259.

Roozen I., and C. Claeys. 2010. The relative effectiveness of celebrity endorsement for print advertisement. Review of Business and Economics 1: 76-89.

Roy S., and A. Pansari. 2014. Owner or endorser? Investigating the effectiveness of celebrity owners of sports teams as endorsers. International Journal of Sports Marketing and Sponsorship 15 (2):12 - 29.

Roy, S., V. Jain, and P. Rana. 2013. The moderating role of consumer personality and source credibility in celebrity endorsements. Asia-Pacific Journal of Business Administration 5 (1): 72-88.

Saleem, F. 2007. Young adults perception towards celebrity endorsement: A comparative study of single and multiple celebrities endorsements. European Journal of Economic 8: 128-139.

Schiffman, L. G, and L. L. Kanuk. 2014. Consumer Behaviour (11 ${ }^{\text {th }}$ ed.). New York: Prencite Hall.

Shimp, T. A. 2010. Advertising Promotion and Other Aspects of Integrated Marketing Communications ( $8^{\text {th }}$ ed.). 
Mason, USA: South-Western Cengage Learning.

Shuart, J. 2007. Heroes in sport: Assessing celebrity endorser effectiveness. International Journal of Sports Marketing and Sponsorship 8 (2): 11-25.

Silvera D. H., and B. Austad. 2004. Factors predicting the effectiveness of celebrity endorsement advertisements. European Journal of Marketing 38: 1509-1528.

Solomon, R. S. 2011. Consumer Behavior, Buying, Having, and Being, $9^{\text {th }}$ Edition, Boston: Pearson.

Tripp, C., T. D. Jensen, and L. Carlson. 1994. The effects of multiple product endorsements by celebrities on consumer attitudes and intentions. Journal of Consumer Research 20 (4): 104-114.

Wang, H., P., Chao, and J. Y. Wang. 2015. Effects of fit, consumer involvement and the number of celebrities on consumer behavior in an emerging market. Journal of International Consumer Marketing 27: 388-402.

Wei K. K., and W. Y. Li. 2013. Measuring the impact of celebrity endorsement on consumer behavioural intentions: A study of Malaysian consumers. International Journal of Sports Marketing and Sponsorship $14(3): 2-22$.

Yang, S. C., W. C. Hung, K. Sung, and C. K. Farn. 2006. Toward e-tailers from the elaboration likelihood model perspective. Psychology \& Marketing 23 (5): 429-445.

Zaichkowsky, J. 1985. Measuring the Involvement Construct. Journal of Consumer Research 12:341-352. 
